\title{
Is undergraduate programme accreditation influenced by educational public policy quality indicators? An exploratory study of the Chilean higher education quality \\ assurance system.
}

\author{
Oscar Jerez ${ }^{\mathrm{a} *}$, César Orsini ${ }^{\mathrm{a}, \mathrm{b}}$, Beatriz Hasbún ${ }^{\mathrm{a}}$, Eduardo Lobosa ${ }^{\mathrm{a}}, \& \operatorname{Marcos}_{\text {Muñoz }}^{\mathrm{a}}$ \\ ${ }^{a}$ Teaching and Learning Centre, Faculty of Economics and Business, University of Chile. Diagonal Paraguay \\ 257, Nivel -1, Torre 26. Santiago - Chile. \\ ${ }^{\mathrm{b}}$ Faculty of Dentistry, Universidad de los Andes, Chile. \\ *Corresponding Author. E-mail: ojerez@fen.uchile.cl - Telephone: +56 229772030
}

\begin{abstract}
In Chile, as well as in most of Latin America, public policies for higher education have recently adopted a focus on quality assurance and accreditation systems. Uncertainty, however, still exists in terms of the quality assurance consistency in the current Chilean accreditation system, especially in terms of the relation between public policy quality indicators for higher education and their relation to accreditation outcomes. Therefore, the aim of this study was to make a first explorative attempt to investigate the relationships between these indicators and the results of undergraduate programme accreditation. We hypothesised that public policy quality indicators of first year of study dropout, employment at graduation, and ratio of real to formal graduation time frame would be strongly correlated to undergraduate programme accreditation as well as largely explaining its accreditation-year variance. By means of correlation and multiple regression analyses we found small-sized associations, being first year dropout the only significant predictor of programme accreditation, explaining a $9.4 \%$ of its variance. These results raise questions regarding the consistency between the aims of public policy for higher education and the current accreditation system. This study should be of value to policy-makers, managers, and curriculum developers in terms of this initial analysis of the consistency between quality indicators and the accreditation system. Further research is necessary to make a systematic and in-depth assessment of the impact of quality assurance mechanisms to provide better rationale for making important decisions such as when defining the characteristics of the accrediting institutions as well as for establishing effective ways to achieve the proposed public policy objectives.
\end{abstract}

Keywords: Accreditation; Chile; Quality assurance; Quality enhancement; Higher education policy. 


\section{Introduction}

The past decade has seen the rapid development of research and interventions towards quality assurance (QA) systems in several higher education (HE) contexts, such as in European (Capano 2014; Enders and Westerheijden 2014; Gornitzka and Stensaker 2014; Lucas 2014), Asian (Hou et al. 2014; Jarvis 2014; Lo 2014; Wang 2014) and North American settings (Weinrib and Jones 2014). By contrast, in Chile as well as in all Latin American HE contexts, there is much less information about QA systems and their predictors and outcomes, where current research has been mostly focused on institutional accreditation and its correlated variables (Cancino and Schmal 2014; Martínez et al. 2015). As such, this paper aims to make a first explorative attempt to investigate the relationship between public policy quality indicators and undergraduate programme accreditation decisions. The paper first gives a brief overview of theoretical frameworks on HE accreditation, followed by the evolution of the Chilean HE accreditation system and its current quality indicators. The second section deals with the purpose and research questions, followed by the methods that outline variables considered, sources and data collection and analysis procedures. Results are then presented in terms of descriptive statistics, correlational and regression analyses. The remaining part of the paper proceeds considering the results, their implications, along with the study's limitations and recommendations for future research.

\section{Background}

Defining the concept of quality is not an easy task and several definitions are found in the literature (Dias Sobrinho 2007; Zúñiga 2007). Jerez (2013) points out, that discussing about quality and processes involved is directly related to the responsibility of different organisations in terms of their effects and impacts. Therefore, quality may be understood as a set of attributes, organised in different dimensions, reflecting the envisioned qualities and positive outcomes that a higher education institution declares to take responsibility of and promote over society, the environment and the generation of knowledge.

On the other hand, QA frameworks are described to be mainly derived from two models: the French model, which is based on being quality assured by external regulatory bodies, and the English model that is centred on institutions' self-assessment (Van Vught and Westerheijden 1994). Currently, it is common to observe a mixture of these two frameworks. For instance, Van Vught and Westerheijden (1994) analysed the QA frameworks implemented in USA, Canada and Western Europe, finding four common elements: (1) The existence of a QA 
regulatory body, which is autonomous from the current government politics; (2) Institutional self-assessment, to generate a report informing outcomes and experiences, and to provide faculty a sense of ownership so to faciliate the implementation of change; (3) Peer-review from external experts; (4) and the positive correlation between QA results and public funding received.

Additionally, the way in which institutions understand and implement their QA strategies have been clasified in three mejor models; quality control, quality assurance, and quality promotion (OECD 2009). These areas are related to how institutions respond in terms of the emphasis and approach towards quality, the level and moment of intervention, the regulatory body involved, and on how institutions engage in the QA process (Fig. 1).

\section{[Please insert figure 1 here]}

For the case of Latin America, in general, the implementation of these models has considered governmental, public and decentralized bodies, and specifically in Chile and Mexico it has involved private accreditation bodies (Lemaitre and Zenteno 2012). Moreover, rather than a permanent QA culture there is a reactive response to the mandatory requirement of accreditation so to increase institutional public funding. This leads towards a culture of obedience and to reach minimum standards (Lemaitre and Zenteno 2012).

In Chile, as well as in most of Latin America, public policies for HE, which started in the 1980s with a first phase emphasising on incrementing enrolment rates, have now shifted towards a second phase focusing on QA and accreditation systems (UDUAL 1999). Uncertainty, however, still exists in terms of the QA consistency in the current Chilean accreditation system, especially in terms of the relation between quality indicators for HE promoted by Chilean public policy (detailed below) over the past years and their relation to accreditation outcomes.

\section{The evolution of Chilean HE accreditation system: From incrementing enrolment rates to the promotion of quality.}

Starting in 1980, new educational reforms were introduced in Latin America due to the limited coverage and restricted access to higher education (UDUAL 1999). At that time, HE reforms introduced in Chile were mainly oriented towards three objectives (Brunner 1986): (1) Opening-up the system by promoting the establishment of new and private institutions; (2) diversifying HE by creating a three-hierarchical level of institutions composed 
by Universities (Leading to bachelor and professional degrees), Professional Institutes (Short programmes not necessarily including a bachelor degree) and Technical Centres (Limited to shorter vocational courses leading to technical certificates); and (3) to 'force' universities to diversify their funding sources and partially transfer the cost of state-funded universities to students.

Consequently, the past 30 years have seen a rapid increase in the number of institutions and a significant increment in enrolment rates and coverage of HE (Brunner 1993; Cancino and Schmal 2014). Nevertheless, the initially planned strategy to overcome inequalities has not succeeded in terms of including all socio-economic sectors in enrolment opportunities, retention, and educational achievement (UDUAL 1999). A consequence of the above has been the establishment of a particularly heterogeneous system in terms of focus, quality and funding opportunities (Brunner and Briones 1992), being predominantly a private market-concern where public institutions have experienced an overall enrolment decline (Brunner 1993; Lemaitre 2004).

In 1990, new reforms and policies pertaining HE were introduced, amongst which private universities and professional institutes should undergo accreditation processes (Squella 1990). These policies have been aimed at enhancing the quality, equity, decentralisation and internationalisation of Chilean HE (OECD 2009).

In this scenario, institutional and programme accreditation have been seen as valid and reliable sources to provide the state (public policy) and society (accountability) with means to regulate, guide and lead HE (Cancino and Schmal 2014). The 'Comisión Nacional de Acreditación' (CNA, original for National Accreditation Commission) is the public regulatory body aimed at verifying and promoting the quality of Chilean HE through monitoring, inspecting, and making final decisions on institutional, undergraduate and postgraduate programme accreditation periods, which are expressed as year time-frames, ranging from the CNA evaluation results until a new inspection is due to take place (National Accreditation Commission 2015a).

The accreditation process for both institutions and programmes is voluntary (except for pedagogy and medicine bachelor degrees) and it begins with a self-evaluation report that should follow the guidelines provided by CNA. For programme accreditation, these guidelines are composed by twelve criteria organised in three macro dimensions: (1) Purpose and institutionality; (2) Operational conditions; and (3) Results and selfregulation (National Accreditation Commission 2015b). The former two are mainly qualitative subjective criteria, while the latter includes the reporting of indicators such as first year enrolment, places available, enrolment and employment data, students-body characteristics, first year and overall dropout rate, graduation rate by cohort, and real graduation time frame. This is then followed by an external peer-review visit, which verifies on-site and evaluates the accuracy of the institution or programme's self-evaluation and issues a report. 
Finally, a consensus decision on the accreditation period awarded is made taking into account the selfevaluation report, peer-reviewers report, an additional economic account and final comments from the institution or programme after the peer-reviewers visit (National Accreditation Commission 2015a). In this context, a successful accreditation is considered when the institution or programme increases or maintains the maximum number of awarded accreditation years

Despite its non-compulsory nature and its subjectivity, it is believed that the accreditation process has had a positive impact within HE institutions, which now seems more responsible and efficient to follow government processes and institutional management decisions (IESALC-Unesco 2006). Indeed, after accreditation or because of it, most programmes have declared graduation profiles or expected learning outcomes, and are shifting from an intuitive-based towards an evidence-based approach when making decisions, aspects which had not been taken into account before the accreditation phase started (OECD 2008).

Indicators reflecting learning processes and its open results have been of relevance since the establishment of CNA. This has lead to the creation of the 'Servicio de Información de Educación Superior' (SIES, original for Higher Education Information Service) (OECD 2013), which works providing information for institutions as well as for prospective and current students aiming to guide the decision-making of all stakeholders. Since then, SIES has emphasised the relevance of three quality indicators, these being (1) first year dropout, (2) real to formal graduation time frame, and (3) expected employment and income, all of which should be central concerns for the state, institutions and for students, who should be provided with these data to make informed decisions in a particularly complex context of diversified academic offer (Servicio de Información de la Educación Superior 2014).

These specific indicators were established based on recommendations from the Organisation for Economic Co-operation and Development (OECD) (OECD 2009) and are currently part of the decision-making of institution and programme accreditation. Additionally, in agreement with SIES, the programme 'Mejoramiento de la calidad y la equidad en la educación terciaria' (MECESUP, original for Quality and Equity Improvement Programme in Higher Education), created by the Chilean Ministry of Education with support from a loan by the World Bank, has also incorporated these indicators as part of the expected results of projects aimed at supporting the QA and regulatory structure of HE institutions (OECD 2009).

Moreover, these indicators have been in the centre of HE debate, not only in terms of Chilean QA public policy but also at an international management and research level. In terms of student's dropout, it has been considered as a student progress indicator (Jones-White et al. 2010; Rodríguez-Gómez et al. 2014) and as 
an institutional quality indicator (Schmitz 1993). Graduation time has been referred to as a student success indicator (Jones-White et al. 2010; Ohland et al. 2011), an institutional quality indicator (Schmitz 1993), and a performance-based accountability indicator for institutions (Shin 2010).With regards to employment and income, previous authors have considered these as performance indicators of Universities (Boden and Nedeva 2010; Holmes 2013) and as indicators of the relationship between Institutions and the labour market (Tomlinson 2012).

For instance, previous research has focused on these indicators and on the effects that several variables have over them, such as the quality of tutoring (Arco-Tirado et al. 2011), students' socioeconomic background and financial aid (Aina 2013; Arias Ortiz and Dehon 2013), learning outcomes (Duque et al. 2013), accreditation results (Martínez et al. 2015), programme level of structure (Hovdhaugen 2011), institutional selectivity and expenditures (Webber and Ehrenberg 2010), self-employment support (Greene and Saridakis 2008), gender (Menon et al. 2012), age (Woodfield 2011), and massification of HE (Chan and Lin 2015; Mok 2016) amongst others.

So far, and mainly because of the emphasis that SIES has placed on these indicators as well as due to the incorporation of them into the accreditation criteria, they are being measured transversely and correspond to the few publicly accessible data. Additionally, as MECESUP resources are being invested in projects aimed at improving these indicators (aligned with public policies that seek quality assurance), it would be reasonable to expect a strong association between them and the outcomes of the accreditation process. Therefore, and taking into account the historical evolution of Chilean HE public policy, it is of high relevance to consider the results of the current QA system in terms of the accreditation of institutions and programmes, so that policy makers, managers, and curriculum developers are able to make evidence-based decisions that would ultimately benefit the quality of Chilean HE.

\section{Purpose and research questions}

In light of the continuous developments of Chilean HE towards an accreditation system that assures quality and considering the relevance towards the three public policy quality indicators over the past years, the aim of this study was to explore the relationship between these indicators and the results of undergraduate programme accreditation. We hypothesised that the quality indicators of (1) first year of study dropout, (2) employment at 
graduation, and (3) ratio of real to formal graduation time frame would be strongly correlated to undergraduate programme accreditation as well as largely explaining its accreditation-year variance. We decided to focus on undergraduate programme accreditation mainly because the indicators are publicly accessible on a programmebasis rather than on an institutional-basis, and also because of the widespread variety of programmes and the relevance that this variable represents for students' decisions when transitioning from secondary to HE. By means of correlation and multiple regression analyses, the following research questions were addressed:

1. What is the correlation between the proposed HE public policy quality indicators and undergraduate programme accreditation?

2. Is undergraduate programme accreditation influenced by the proposed HE public policy quality indicators?

\section{Methods}

\section{Sources and data collection procedures}

The study was conducted between October-December 2015. Data were collected from three open longitudinal national datasets containing information on undergraduate programmes from different Chilean HE institutions (Universities, Professional Institutes and Technical Centres). All datasets collected corresponded to 2015, as these were the most updated data at the time the study took place.

The first source corresponded to data from 'Mi-Futuro' (original for My-Future) (Ministry of Education of Chile 2015), which is a Ministry of Education dependant initiative with the aims of providing high school students valid information concerning employment, future income, and tuition fees, amongst other data from different undergraduate programmes within the spectrum of Chilean HE institutions. It offers support and guidance to students who are finishing secondary education, so they can make an informed decision when choosing where to begin their HE studies. The information reported corresponds to an average of the last three cohorts of each programme, thus our data came from the period between 2012-2015. This dataset was considered to be a valid and reliable source as it contained information collected from institutions such as the above-mentioned CNA, SIES, and a number of University information centres. We collected data on first year 
of study dropout, employment at graduation and real graduation time frame (i.e., the actual number of semesters from enrolment until graduation).

The second source corresponded to CNA itself (National Accreditation Commission 2015a), from which we collected data on institutional and undergraduate programme accreditation period.

In order to corroborate from a third source that the undergraduate programmes reported in Mi-Futuro and CNA were currently active and had students enrolled, we crosschecked the information with data from the National Education Council (National Education Council 2015). The latter is an autonomous institution related to the Ministry of Education that, amongst other roles, delivers public information on the implementation and activity of HE, promoting educational reflection and research. We therefore collected data on the last active year of each programme and the number of students enrolled. Consequently, a programme was considered active if it was included in the 2015 dataset and if it had at least one enrolled student. Additionally, we collected the formal graduation time frame of each programme (i.e., the expected time frame from enrolment until graduation declared by each programme).

We received exemption from approval by the Ethics Committee of the University of Chile since all data came from secondary sources freely available in the public domain.

\section{Variables}

Five variables were included for analyses. The first three corresponded to the public policy quality indicators of (1) first year of study dropout, (2) employment at graduation and (3) ratio of real to formal graduation time frame. The fourth and fifth corresponded to (4) institutional and (5) undergraduate programme accreditation periods.

First year of study dropout and employment at graduation were reported, respectively, as the percentage of students dropping out in first year and as the percentage of students being employed after one year of graduation. To derive the ratio of real to formal graduation time frame, we computed one measure by dividing the real graduation length on the formal length. The use of this measure made possible to standardise the variable of graduation time frame amongst different programmes.

Both accreditation periods were expressed in number of years. The minimum accreditation period given by CNA corresponds to zero, which means no accreditation is given to the institution or undergraduate programme, and the maximum corresponds to seven years. This means that, the higher the accreditation period 
given, the higher should be the quality of the institution or undergraduate programme being evaluated. Consequently, the evaluation and years of accreditation given by CNA-related agencies were considered as a proxy measure of the quality level of programmes and institutions.

\section{Data analysis}

We conducted all data analysis using the SPSS ${ }^{\circledR}$ software package version 20.0 , with the alpha level set at $\leq 0.05$. Data from the three-abovementioned sources were merged into one dataset following three steps. First, we merged the dataset of Mi-Futuro and CNA, and listwise deleted missing values for the variables of first year of study dropout, employment at graduation, real graduation time frame and institutional and programme accreditation. Second, from the data of the National Education Council we added the variable of formal graduation time frame and listwise deleted missing values. Finally, we reached the final sample of Chilean undergraduate programmes after crosschecking the data from the previous phases with the aforementioned National Education Council information and excluding all inactive programmes (i.e., not being active during 2015 or not having students enrolled).

After checking for the assumptions of the general linear model of normal distribution of data, linearity of relationships between variables, independent errors, homoscedasticity, and no multicollinearity (Field 2013), we computed descriptive statistics (Means and Standard Deviations) and basic correlation coefficients between all variables in order to answer the first research question. Based on the strength of the correlation coefficients and on the theoretical importance of each predictor variables, a three stage hierarchical multiple regression was planned to test whether undergraduate programme accreditation was influenced by the three variables representing public policy quality indicators, so to answer the second research question. A hierarchical regression method was used to add the three indicators in different blocks and to inform whether these additions improved the model for predicting years of programme accreditation. Moreover, confidence intervals and significance tests of the model parameters were all estimated by using bootstrap robust methods, which provided an accurate estimate of the true population's b-values for each quality indicator.

As a rule of thumb for sample size in regressions analyses, there should be at least 15 cases of data per predictor (Miles and Shevlin 2001). However, we wanted to make sure that our sample size met the effect sizes and power that we aimed to detect, therefore we conducted an a priori power analysis using the G*Power 
software version 3.1.9.2. With the three predictors and intending an effect size of 0.1 , alpha level of 0.05 and power of 0.8 , the resulting sample size was of 107 cases.

Additionally, by meeting the abovementioned assumptions we were able to test the accuracy of our model to different samples and to therefore assess the generalisability of our findings. This cross-validation was based on the value of the adjusted $\mathrm{R}^{2}$, which informs how much variance in the undergraduate programme accreditation period would be accounted for if the model had been derived from the population from which the sample of programmes was obtained. An equal or very close value of the adjusted $R^{2}$ to the value of $R^{2}$, indicates a very good cross-validity of the model (Field 2013).

\section{Results}

\section{Descriptive statistics}

A total of 1,589 undergraduate programmes were retrieved from Mi-Futuro dataset. Of those, 1,019 were kept after screening for missing values on the variables of first year of study dropout, employment at graduation and real graduation time frame. After merging these data with the CNA dataset, the sample was reduced to 764 by excluding programmes that had not been evaluated for accreditation purposes. Afterwards, 12 programmes were considered inactive and were discarded, as they had no students enrolled in the last academic year. Therefore the final sample of undergraduate programmes included in our analyses was of 752, which corresponded to 64 different institutions: 48 universities, 12 professions institutes and 4 technical centres. This final sample was well above the resulting number from the power analysis.

As can be seen in table 1, means and standard deviations for programme and institutional accreditation were similar, with a respective $4.76(1.60)$ and 4.78 (1.63) mean accreditation years out of the maximum period of seven years. Students dropping out on the first year reached $21 \%$, while $81 \%$ of them reported being employed on their first year as graduates. Moreover, concerning graduation time frame, it took students 1.37 more semesters to complete their studies than the formal duration planned by each programme.

[Please insert table 1 here] 


\section{Correlation Analyses}

We inspected the bivariate correlations between first year of study dropout, employment at graduation, ratio of real to formal graduation time frame and institutional and undergraduate programme accreditation periods (Table 1). All correlations were significant and were in the expected direction, showing that as accreditation periods increased (for both programmes and institutions) students' dropout and ratio of graduation time frame decreased, and employment at graduation increased.

Institutional and programme accreditation showed a positive but small-sized correlation (.41). Hence as institutions result in successful accreditation evaluations, an important number of undergraduate programmes may not show the same outcomes, therefore justifying the use of both accreditation approaches in the Chilean higher education system.

Concerning programme accreditation and the three public policy quality indicators, the strongest correlation was with first year dropout that showed a small negative correlation (-.31). This was followed by both, employment at graduation and ratio of real to formal graduation time frame, which showed respectively very small positive (.09) and negative correlations (-.09). Furthermore, first year dropout showed, respectively, negative and positive small-sized correlations with employment at graduation (-.33) and ratio of real to formal graduation time frame (.31). Finally, employment at graduation showed a very small negative correlation with ratio of real to formal graduation time frame (-.10).

Consequently, and due to the small and very small-sized correlations (Creswell 2012) between undergraduate programme accreditation and the three quality indicators declared by the Chilean higher education public policy, it was important to further examine the influence of these indicators over the variance of undergraduate programmes accreditation.

\section{Regression Analyses}

To investigate the influence of the three quality indicators on undergraduate programme accreditation, we conducted a three-block hierarchical regression analysis (Table 2). In the first block we examined the unique effect of first year dropout on programme accreditation, since this variable showed the strongest correlation with the latter. In the second block we incorporated the effect of ratio of real to formal graduation time frame and, 
finally, in the third block we incorporated the effect of employment at graduation, which had reported the weakest correlation score with programme accreditation.

\section{[Please insert table 2 here]}

As shown in table 2, the three blocks explained $9.4 \%$ of the variability in undergraduate programme accreditation. What is interesting in this data is that the change in $\mathrm{R}^{2}$ was non-significant and therefore the variability in programme accreditation did not increase when ratio of real to formal graduation time frame and employment at graduation were included in block 2 and 3. Thus, first year of study dropout seems to be the only contributor to the $9.4 \%$ variation, and other external criteria should explain the remaining $90.6 \%$ of variance in undergraduate programme accreditation.

Additionally, the adjusted $\mathrm{R}^{2}$ was close to the value of $\mathrm{R}^{2}$, with a small difference of $0.01,0.02$ and 0.03 respectively for each block, indicating that the cross-validity of the model was very good (Field 2013). These shrinkages mean that if the model were derived from the population rather than from our sample, it would account for approximately $0.1 \%, 0.2 \%$ and $0.3 \%$ less variance in programme accreditation. As for the goodness of fit of the model to the data, all three blocks report significant F-ratios, with block 1 reporting the better fit. As variables in block 2 and 3 were included, the ability to predict programme accreditation decreased.

As for the model parameters, we can see from block 3 that first year of dropout was a significant negative predictor and it was the only variable that explained variation of undergraduate programme accreditation, even when controlling for the effects of ratio of real to formal graduation time frame and employment at graduation. Both latter variables were found to be non-significant and did not contribute to predicting programme accreditation. Therefore, lower scores of first year dropout predicted more accreditation years given by CNA-dependant agencies to different undergraduate programmes, however, change in the ratio of real to formal graduation time frame and employment at graduation did not predict any changes in the outcome of undergraduate programme accreditation.

\section{Discussions}

The present study was designed to explore the associations between public policy quality indicators for Chilean $\mathrm{HE}$ and the results from undergraduate programmes accreditation. The quality indicators of first year dropout, 
employment at graduation and real to formal graduation time frame were hypothesised to show a strong association and to largely explain the variance in the outcomes of the accreditation process for undergraduate programmes.

With respect to the first research question, it was found that the three quality indicators and both programme and institution accreditation results were significant and in the expected direction. The observed correlations, however, represented small and very small effect sizes (Table 1). These findings suggest that the accreditation status of programmes and institutions does not necessarily imply an achievement of the proposed quality indicators. Amongst the small correlations reported, first year dropout showed the highest association with accreditation results, which could be attributed to the large amount of funds destined by public policy to increase retention rates (Ministry of Education of Chile 2014). These results are in agreement with those obtained by Martínez et al. (2015), where dropout rates were the only quality indicator that showed a significant association with the results from undergraduate programme accreditation . Moreover, the three quality indicators showed weak correlations amongst them. These findings raise questions on the relevance that the accreditation process gives to the three public policy quality indicators.

Additionally and despite being positive, the correlation between institutional and programme accreditation was small-sized. This finding was unexpected and suggests that an institution with a successful accreditation result might not be transferring these skills and good practices into their different programmes. Furthermore, a consequence of the expanding numbers of educational institutions is that a given programme might be offered across different campuses, which might have different faculty, facilities, and even different curricula (Guzmán and Bustos 2016). Therefore, this apparent inconsistency in the Chilean QA system highlights the needs to continue using both institutional and programme accreditation methods.

The second question in this research referred to the influence that quality indicators have on the results of programme accreditation. Contrary to expectations, this study found that the three quality indicators only explained a $9.4 \%$ of the variance in programme accreditation results. Indeed, only first year dropout was found to be a significant predictor, questioning the relevance that real to formal graduation time frame and employment at graduation have in the accreditation decision-making process. Would it be the case that accreditation results are giving more weight to other variables? This is consistent with data obtained by Cancino \& Schmal (2014), who recently reported a strong association, in Chilean HE, between years of institutional accreditation and variables such as accredited postgraduate programmes, public funded research projects, full time faculty and staff awarded with doctoral degrees. 
An implication of the above is that the attributes of the Chilean QA system are more related to intrinsic institutional characteristics rather than to their effects on students' learning or outcomes. It seems that current accreditation results make sense in the extent that programmes are internally consistent with their actions and are not necessarily determined by the effects of these actions. In other words, the overall concept of quality in $\mathrm{HE}$ is currently being focused on the operational conditions of programmes and institutions rather than on their effects. Although these processes are important for QA, they start losing their meaning or value if they are not related to the effects they have beyond the university context, that is, their public impact.

Our findings, while preliminary, suggest that further research and evidence is required before introducing new reforms to the accreditation system. The three quality indicators have been considered over the past years as central for the development of MECESUP funded projects, which have benefited a number of higher education institutions with resources to strengthen their outcomes in terms of these indicators. Nevertheless, they appear to have low impact on accreditation outcomes.

Current public funded projects, however, are increasingly giving more relevance and showing more alignment with the criteria defined by HE policy (Ministry of Education of Chile 2014), thus linking the action of public policy with QA systems. This shows signs of a transitioning QA system, which is relying on various indicators and instruments to assure the quality of $\mathrm{HE}$ without necessarily following an evidence-based standard. A key policy priority should be therefore to plan for the QA system and HE public policy to work under the same quality indicators, if not, it will be difficult to move forward and implement evidence-based changes aimed to improve the quality of Chilean HE. This would make possible for both institutional and programme accreditation results to be a reliable determinant to guide the public policy decision-making process. Additionally, this would also allow comparability and benchmarking, for instance, between research and teaching institutions based on the same indicators. As such, one of the challenges ahead is the implementation of a mixed model of accreditation, which incorporates both- criteria and their specific standards, so as to guide the achievement of those criteria.

The good practice of Chilean public policy to allocate funds for innovation and faculty development in HE through the MECESUP initiative should not be discontinued, however, it needs some adjustments, as these funds currently support local appraisal of institutions and do not arise from a general diagnosis of the Chilean HE system. Greater efforts are needed to ensure that public policy allocates funds directly intended to guide institutions on the implementation of practices that have greater effects on the previously defined quality indicators. The findings of this research provide initial insights for the latter, as the decrease in first year dropout 
was the only significant predictor of programme accreditation results, and this coincides with the recent efforts and resources assigned by public policy to tackle dropout rates (Ministry of Education of Chile 2014).

The scope of this study was limited in terms of the sample, which was constrained by the publicly available data on the quality indicators and by the limited number of programmes that have subjected themselves to the voluntarily accreditation process, which make these findings less generalizable to the entire system. .An additional uncontrolled factor was the absence of explicit variables to explain the committee members' decision on year of programme accreditation, such as committee members' characteristics or the assessments of self-evaluations reports and on-site visits, thus limiting a deeper understanding of the phenomenon.

\section{Conclusion}

The results of this investigation show weak associations between the quality indicators of first year dropout, real to formal graduation times frame, employment at graduation and the results of undergraduate programme accreditation, being first year dropout the only significant predictor of programme accreditation. This is the first study to explore the associations between these variables and to generate evidence to inform the planned QA reforms in HE that are being currently discussed. Taken together and despite its exploratory nature, the present study should prove to be particularly valuable to policy makers, managers, and curriculum developers as it raises important questions in term of the consistency between public policy quality indicators and the current accreditation system..

As such, the findings of this study have a number of implications. In first place, considering the small correlation found between institutional and programme accreditation, it is recommended that Chilean HE continues with both processes, despite the current international trend that focuses accreditation at an institutional level only, arguing that both are strongly correlated and as such, institutional accreditation should inform and be a reflection of the quality of the imparted programmes, which would additionally result in cost savings for the institution (Westerheijden et al. 2014).

In second place, the weak predictive role of first year dropout and the non-significant predictive role of real to formal graduation time frame and employment at graduation reflect the subjectivity of the programme accreditation process. Therefore, it would be beneficial for the HE system if the criteria by which CNA awards accreditation years were made clearly explicit and accessible to all stakeholders. 
In third place, these findings might be explained due to differences across disciplines and across labour markets. For instance, if employment decreases in certain discipline because of low demands from the market, it does not necessarily imply low quality of programmes. Therefore, it would be reasonable to weight these indicators considering the nature of disciplines and their social value.

In terms of directions for future research, further work is necessary to make a systematic assessment of the impact of the current QA mechanisms. As Lemaitre (2004) suggests, this would provide better background for making important decisions such as when defining the characteristics of the accrediting institutions and agencies as well as for establishing the most effective ways to achieve the proposed public policy objectives. A natural progression of this exploratory study is to deepen the analysis and, for instance, analyse the accreditation results by disciplines or clustering in terms of different accrediting agencies to investigate their impact on the results of programme accreditation. Additionally, and considering that Chile has led the development of Latin American QA systems (OECD 2013), improvements in Chilean HE might as well inspire future developments in other contexts. 


\section{References}

Aina C (2013) Parental background and university dropout in Italy. Higher Education, 65:437-456. doi: 10.1007/s10734-012-9554-Z

Arco-Tirado JL, Fernández-Martín FD, Fernández-Balboa JM (2011) The impact of a peer-tutoring program on quality standards in higher education. Higher Education, 62:773-788. doi: 10.1007/s10734-011-9419-x

Arias Ortiz E, Dehon C (2013) Roads to Success in the Belgian French Community's Higher Education System: Predictors of Dropout and Degree Completion at the University Libre de Bruxelles. Research in Higher Education, 54:693-723. doi: 10.1007/s11162-013-9290-y

Boden R, Nedeva M (2010) Employing discourse: universities and graduate “employability.” Journal of Education Policy, 25:37-54.

Brunner J (1986) Informe sobre la Educación en Chile [Report on Chilean Education]. Santiago de Chile: FLACSO. Retrieved from http://flacsochile.org/biblioteca/pub/publicos/1986/libro/000033.pdf

Brunner J (1993) Chile's higher education: between market and state. Higher Education, 25:35-43. doi: 10.1007/BF01384040

Brunner J, Briones G (1992) Higher education in Chile effects of the 1980 reform. Santiago de Chile: FLACSO. Retrieved from http://flacsochile.org/biblioteca/pub/memoria/1992/000531.pdf

Cancino V, Schmal R (2014) Sistema de Acreditación Universitaria en Chile: ¿Cuánto hemos avanzado? [University Accreditation System in Chile: How much have we advanced?]. Estudios Pedagogicos, 40:4160. doi: $10.4067 / \mathrm{S} 0718-07052014000100003$

Capano G (2014) The re-regulation of the Italian university system through quality assurance. A mechanistic perspective. Policy and Society, 33:199-213. doi: 10.1016/j.polsoc.2014.08.001

Chan S-J, Lin L-W (2015) Massification of higher education in Taiwan: Shifting pressure from admission to employment. Higher Education Policy, 28:17-33.

Creswell JW (2012) Educational research: Planning, conducting, and evaluating quantitative and qualitative research. Upper Saddle River, New Jersey

Dias Sobrinho J (2007) Acreditación de la educación superior en América Latina y el Caribe [Higher education 
accreditation in Latin America and the Caribbean]. In: Mundiprensa (ed) Report Higher Education in the World - Informe: La educación superior en el mundo 2007 : Acreditación para la garantía de la calidad: ¿Qué está en juego? [World higher education 2007: Accreditation to guarantee quality: What is at stake?]. Madrid/ Barcelona: Global University Network for Innovation (GUNI/UNESCO), Ediciones Mundi-Prensa, $\mathrm{p} 14$.

Duque LC, Duque JC, Suriñach J (2013) Learning outcomes and dropout intentions: an analytical model for Spanish universities. Educational Studies, 39:261-284.

Enders J, Westerheijden DF (2014) The Dutch way of New Public Management. Policy and Society, 33:189198. doi: 10.1016/j.polsoc.2014.07.004

Field A (2013) Discovering statistics using IBM SPSS statistics. Sage, London

Gornitzka A, Stensaker B (2014) The dynamics of European regulatory regimes in higher education -

Challenged prerogatives and evolutionary change. Policy and Society, 33:177-188. doi:

10.1016/j.polsoc.2014.08.002

Greene FJ, Saridakis G (2008) The role of higher education skills and support in graduate self-employment. Studies in Higher Education, 33:653-672.

Guzmán F, Bustos M (2016) El 76\% de los programas de educación superior no están acreditados [76\% of higher education programmes are not accredited]. In: La Tercera. http://fw.to/wuZM1SM. Accessed 17 Feb 2016

Holmes L (2013) Competing perspectives on graduate employability: possession, position or process? Studies in Higher Education, 38:538-554.

Hou AY-C, Chen KH-J, Morse R (2014) Transforming the quality assurance framework for Taiwanese higher education: A glonacal context. Policy and Society, 33:275-285. doi: 10.1016/j.polsoc.2014.09.001

Hovdhaugen E (2011) Do structured study programmes lead to lower rates of dropout and student transfer from university? Irish Educational Studies, 30:237-251.

IESALC-Unesco (2006) Informe sobre la Educación Superior en américa latina y el caribe. 2000-2005. La metamorfosis de la educación superior. [Report on Latin American and Caribbean higher education. 20002015. The methamorphosis of higher education]. Caracas Venezuela: IESALC/UNESCO. Retrieved from 
www.iesalc.unesco.org.ve.

Jarvis DSL (2014) Policy transfer, neo-liberalism or coercive institutional isomorphism? Explaining the emergence of a regulatory regime for quality assurance in the Hong Kong higher education sector. Policy and Society, 33:237-252. doi: 10.1016/j.polsoc.2014.09.003

Jerez O (2013) Calidad en la Educación Superior en América Latina: Contexto y Perspectivas. [Quality in Latin American Higher Education: Context and Perspectives]. In: Roca C (ed) Congreso Centroamericano de Educación Superior. Consejo Superior Universitario Centroamericano, Ciudad de Guatemala, Guatemala,

Jones-White DR, Radcliffe PM, Huesman Jr RL, Kellogg JP (2010) Redefining student success: Applying different multinomial regression techniques for the study of student graduation across institutions of higher education. Research in Higher Education, 51:154-174.

Lemaitre M (2004) Mecanismos de aseguramiento de la calidad: respuesta a los desafíos del cambio en la educación superior [Quality assurance mechanisms: Answers to the challenges of current changes in highe education]. Calidad en la Educación, 21:87-106.

Lemaitre MJ, Zenteno ME (2012) Aseguramiento de la calidad en Iberoamérica [Quality assurance in IberoAmerica]. Educación Superior-Informe 2012. Santiago de Chile

Lo WYW (2014) Think global, think local: The changing landscape of higher education and the role of quality assurance in Singapore. Policy and Society, 33:263-273. doi: 10.1016/j.polsoc.2014.09.002

Lucas L (2014) Academic resistance to quality assurance processes in higher education in the UK. Policy and Society, 33:215-224. doi: 10.1016/j.polsoc.2014.09.006

Martínez A, Borjas M, Herrera M, Valencia J (2015) Relationship between measures of academic quality and undergraduate student attrition : the case of higher education institutions in the Colombian Caribbean region. Higher Education Research \& Development, 34:1192-1206. doi:

$10.1080 / 07294360.2015 .1024622$

Menon ME, Pashourtidou N, Polycarpou A, Pashardes P (2012) Students' expectations about earnings and employment and the experience of recent university graduates: Evidence from Cyprus. International Journal of Educational Development, 32:805-813. doi: 10.1016/j.ijedudev.2011.11.011

Miles J, Shevlin M (2001) Applying regression and correlation: A guide for students and researchers. Sage, 
London

Ministry of Education of Chile (2015) Mi Futuro. http://www.mifuturo.cl/. Accessed 1 Oct 2015

Ministry of Education of Chile (2014) Beca de nivelación académica para estudiantes de educación superior, Términos de referencia [Reference terms for the Scholarship of Academic Leveling for Higher Education $\begin{array}{lllll}\text { Students]. } & \text { Santiago } & \text { de } & \text { Chile. } & \text { Retrieved }\end{array}$ http://www.mecesup.cl/index2.php?id_portal=59\&id_seccion=4212\&id_contenido=30225

Mok KH (2016) Massification of higher education, graduate employment and social mobility in the Greater China region. British Journal of Sociology of Education, 37:51-71.

National Accreditation Commission (2015a) Website of the National Accreditation Commission. www.cnachile.cl. Accessed 10 Oct 2015

National Accreditation Commission (2015b) Criterios de evaluación para la acreditación de carreras profesionales [Evaluation Criteria for the Accreditation of Bachelor Degrees]. Santiago de Chile. Retrieved from https://www.cnachile.cl/Criterios y Procedimientos/DJ 009-4 Criterios.pdf

National Education Council (2015) Website of the National Education Council. www.cned.cl. Accessed 5 Oct 2015

OECD (2009) Reviews of National Policies for Education: Tertiary Education in Chile. Santiago de Chile.

Retrieved from http://www.oecd.org/edu/skills-beyond-

school/reviewsofnationalpoliciesforeducationtertiaryeducationinchile.htm

OECD (2008) Tertiary Education for the Knowledge Society - OECD Thematic Review of Tertiary Education: Synthesis Report. Retrieved from http://www.oecd.org/dataoecd/20/4/40345176.pdf

OECD (2013) El aseguramiento de la Calidad en la Educación Superior en Chile 2013 [Quality assurance of higher education in Chile 2013]. Santiago de Chile. Retrieved from http://portales.mineduc.cl/usuarios/1234/doc/201310151024490.2012\%20OCDEAseguramiento\%20Calid ad.pdf

Ohland MW, Brawner CE, Camacho MM, et al (2011) Race, gender, and measures of success in engineering education. Journal of Engineering Education, 100:225.

Rodríguez-Gómez D, Feixas M, Gairín J, Muñoz JL (2014) Understanding Catalan university dropout from a 
cross-national approach. Studies in Higher Education, 40:690-703. doi: 10.1080/03075079.2013.842966

Schmitz CC (1993) Assessing the Validity of Higher Education Indicators. The Journal of Higher Education, 64:503-521.

Servicio de Información de la Educación Superior (2014) Panorama de la educación superior en Chile 2014

[Chilean higher education prospect 2014]. Santiago de Chile. Retrieved from

http://www.mifuturo.cl/images/Estudios/Estudios_SIES_DIVESUP/panorama_de_la_educacion_superior _2014_sies.pdf

Shin JC (2010) Impacts of performance-based accountability on institutional performance in the U.S. Higher Education, 60:47-68. doi: 10.1007/s10734-009-9285-y

Squella A (1990) La Ley Orgánica Constitucional de Enseñanza (No. 18.962) [Organic teaching constitutional law (No. 18.962)]. In: Lemaitre M (ed) La Educación Superior en Chile: un Sistema en Transición [Higher education in Chile: A system in transition]. ColecciónForo de la EducaciónSuperior, CPU, Santiago de Chile,

Tomlinson M (2012) Graduate Employability: A Review of Conceptual and Empirical Themes. Higher Education Policy, 25:407-431. doi: 10.1057/hep.2011.26

UDUAL (1999) Historia de las Universidades de América Latina [History of Latin American Universities], 1st edn. Unión de Universidades de América Latina, Cuidad Universitaria, Mexico

Van Vught FA, Westerheijden DF (1994) Towards a general model of quality assessment in higher education. Higher Education, 28:355-371.

Wang L (2014) Quality assurance in higher education in China: Control, accountability and freedom. Policy and Society, 33:253-262. doi: 10.1016/j.polsoc.2014.07.003

Webber DA, Ehrenberg RG (2010) Do expenditures other than instructional expenditures affect graduation and persistence rates in American higher education? Economics of Education Review, 29:947-958. doi: 10.1016/j.econedurev.2010.04.006

Weinrib J, Jones GA (2014) Largely a matter of degrees: Quality assurance and Canadian universities. Policy and Society, 33:225-236. doi: 10.1016/j.polsoc.2014.07.002

Westerheijden DF, Stensaker B, Rosa MJ, Corbett A (2014) Next generations, catwalks, random walks and arms 
races: Conceptualising the development of quality assurance schemes. European Journal of Education, 49:421-434.

Woodfield R (2011) Age and first destination employment from UK universities: are mature students disadvantaged? Studies in Higher Education, 36:409-425.

Zúñiga M (2007) Algunas consideraciones sobre el aseguramiento de la calidad [A few considerations about quality assurance]. In: Ayarza H, Cortadillas J, González LE, Saavedra G (eds) Acreditación y dirección estratégica para la calidad [Accreditation and Strategic direction for Quality]. Santiago de Chile: CINDA, pp 65-73. 
Figure 1 Higher Education quality assurance models (Adapted from OECD 2009)

Type I: Traditional

Quality Control

Institutional

Ex-post

Reactive

Response

Evaluation Focus

Regulatory Body Institutional (intern)
Type II: Transitional

Quality Assurance

Academic Units

Ex-ante

Preventive

Output

Institutional or external regulatory body (National or international)
Type III: Consolidation

Quality Promotion

Institutional and Academic Units

Permanent

Cultural

\section{Process}

Institutional or external regulatory body (National or international)
Engagement
Compulsory
Voluntary
Voluntary 
Table 1 Correlations and Descriptive Statistics of public policy quality indicators and institutional and undergraduate programme accreditation.

\begin{tabular}{|c|c|c|c|c|c|}
\hline & 1 & 2 & 3 & 4 & 5 \\
\hline \multicolumn{6}{|l|}{$\begin{array}{l}\text { 1. Undergraduate programme } \\
\text { accreditation }\end{array}$} \\
\hline 2. First year dropout & $-.31 * *$ & & & & \\
\hline 3. Employment at graduation & $.09 *$ & $-.33 * *$ & & & \\
\hline $\begin{array}{l}\text { 4. Ratio of real to formal graduation time } \\
\text { frame }\end{array}$ & $-.09 * *$ & $.31 * *$ & $-.10 * *$ & & \\
\hline 5. Institutional accreditation & $.42 * *$ & $-.34 * *$ & $.16^{* *}$ & $.11 * *$ & \\
\hline M & 4.76 & 0.21 & 0.81 & 1.37 & 4.78 \\
\hline SD & 1.60 & 0.11 & 0.15 & 0.20 & 1.63 \\
\hline
\end{tabular}

Note: $\mathrm{N}=752 .{ }^{*} \mathrm{p}<.05 .{ }^{* *} \mathrm{p}<.01$ 
Table 2 Hierarchical multiple regression analysis predicting undergraduate programme accreditation.

\begin{tabular}{|c|c|c|c|c|c|c|c|c|}
\hline & Predictor & b (CI's) & SE & $\beta$ & $\mathrm{R}^{2}$ & $\mathrm{R}_{\text {adj }}^{2}$ & $\Delta \mathrm{R}^{2}$ & $\mathrm{~F}$ \\
\hline \multirow[t]{2}{*}{ Block 1} & & & & & .094 & .093 & $.094 * * *$ & $78.01 * * *$ \\
\hline & First year attrition & $\begin{array}{c}-4.55^{* *} \\
(-5.68,-3.37)\end{array}$ & 0.55 & -.31 & & & & \\
\hline \multirow[t]{3}{*}{ Block 2} & & & & & .094 & .092 & .000 & $38.95 * * *$ \\
\hline & First year dropout & $\begin{array}{c}-4.55^{* *} \\
(-5.71,-3.38)\end{array}$ & 0.56 & -.31 & & & & \\
\hline & Ratio grad time & $\begin{array}{c}0.01 \\
(-0.58,0.58)\end{array}$ & 0.29 & .01 & & & & \\
\hline \multirow[t]{4}{*}{ Block 3} & & & & & .094 & .091 & .000 & $26.01 * * *$ \\
\hline & First year attrition & $\begin{array}{c}-4.64 * * \\
(-5.82,-3.40)\end{array}$ & 0.60 & -.31 & & & & \\
\hline & Ratio grad time & $\begin{array}{c}0.02 \\
(-0.58,0.58)\end{array}$ & 0.29 & .01 & & & & \\
\hline & $\begin{array}{l}\text { Employment at } \\
\text { graduation }\end{array}$ & $\begin{array}{c}-0.17 \\
(-0.86,0.54)\end{array}$ & 0.38 & -.02 & & & & \\
\hline
\end{tabular}

Note: Ratio grad time, Ratio of real to formal graduation time frame; b, unstandardized beta; CI's, $95 \%$ bias corrected and accelerated confidence intervals; SE, standard error of the estimate; $\beta$, standardized beta; $R^{2}$ adj, Adjusted $\mathrm{R}^{2}, \Delta \mathrm{R}^{2}$, change in $R^{2}$; F, ANOVA test. Confidence intervals and standard errors based on 1000 bootstrap samples. ${ }^{* * *} \mathrm{p}<0.001 ;{ }^{* *} \mathrm{p}<0.01 ;{ }^{*} \mathrm{p}<0.05$ 